\title{
The future of reference II
}

\section{A panel discussion held at the University of Texas at Austin, Spring 1989.}

$\mathbf{A}$ second program on the future of reference, "A Paradigm of Academic Library Organization," was held at the University of Texas at Austin General Libraries during the Spring of 1989. Where the first program (see C $b R L$ News, October 1988, pp . 578-89) looked at the need for the reference desk and its associated procedures, the second program expanded this examination of reference services to include an entirely new paradigm, or model, of service.

The program was sponsored by the General Library's Reference and Information Services Committee. The attendees included academic librarians and administrators from the General Libraries and the Tarlton Law Library, librarians from the central Texas area, library school faculty and students, paraprofessionals, and general faculty and students.
The keynote address was given by Francis Miksa, professor, Graduate School of Library and Information Science. His remarks were followed by responses from Lynne Brody, head librarian of the Undergraduate Library, and Cheryl Knott Malone, reference librarian, Perry-Castañeda Library Reference Services Department, both at the University of Texas at Austin. Their presentations were followed by a discussion between members of the audience and the panel that continued well past the scheduled end of the session. The three addresses and a summary of the audience's comments by William Kopplin, 1988/89 chair of the Reference and Information Services Committee, are presented here.

\section{The future of reference II: A paradigm of academic library organization}

\author{
By Francis Miksa \\ Professor, Graduate School of Library and Information Science \\ University of Texas at Austin
}

My purpose here is to comment on the future of the academic research library. In making these comments, I will assume what almost no one will deny, that libraries in general and academic re- search libraries in particular are going through a period of significant change. In this light, my task will be twofold-first, to characterize the change that is taking place; and second, to explore implica- 